\title{
Two subphenotypes of septic acute kidney injury are associated with different 90-day mortality and renal recovery
}

Renske Wiersema ${ }^{1,2}$, Sakari Jukarainen ${ }^{2}$, Suvi T. Vaara², Meri Poukkanen ${ }^{3}$, Päivi Lakkisto ${ }^{4}$, Hector Wong ${ }^{5}$, Adam Linder ${ }^{6}$, Iwan C. C. van der Horst ${ }^{1,7}$ and Ville Pettilä ${ }^{2 *}$

\begin{abstract}
Background: The pathophysiology of septic acute kidney injury is inadequately understood. Recently, subphenotypes for sepsis and AKI have been derived. The objective of this study was to assess whether a combination of comorbidities, baseline clinical data, and biomarkers could classify meaningful subphenotypes in septic AKI with different outcomes.

Methods: We performed a post hoc analysis of the prospective Finnish Acute Kidney Injury (FINNAKI) study cohort. We included patients admitted with sepsis and acute kidney injury during the first $48 \mathrm{~h}$ from admission to intensive care (according to Kidney Disease Improving Global Outcome criteria). Primary outcomes were 90-day mortality and renal recovery on day 5 . We performed latent class analysis using 30 variables obtained on admission to classify subphenotypes. Second, we used logistic regression to assess the association of derived subphenotypes with 90day mortality and renal recovery on day 5.

Results: In total, 301 patients with septic acute kidney injury were included. Based on the latent class analysis, a two-class model was chosen. Subphenotype 1 was assigned to 133 patients (44\%) and subphenotype 2 to 168 patients (56\%). Increased levels of inflammatory and endothelial injury markers characterized subphenotype 2 . At 90 days, 29\% of patients in subphenotype 1 and $41 \%$ of patients in subphenotype 2 had died. Subphenotype 2 was associated with a lower probability of short-term renal recovery and increased 90-day mortality.

Conclusions: In this post hoc analysis, we identified two subphenotypes of septic acute kidney injury with different clinical outcomes. Future studies are warranted to validate the suggested subphenotypes of septic acute kidney injury.
\end{abstract}

Keywords: Subphenotypes, Acute kidney injury, Sepsis, LCA, Renal recovery, Mortality

\footnotetext{
* Correspondence: ville.pettila@hus.fi

${ }^{2}$ Division of Intensive Care Medicine, Department of Anesthesiology, Intensive Care and Pain Medicine, University of Helsinki and Helsinki University Hospital, Helsinki, Finland

Full list of author information is available at the end of the article
}

(c) The Author(s). 2020 Open Access This article is licensed under a Creative Commons Attribution 4.0 International License, which permits use, sharing, adaptation, distribution and reproduction in any medium or format, as long as you give appropriate credit to the original author(s) and the source, provide a link to the Creative Commons licence, and indicate if changes were made. The images or other third party material in this article are included in the article's Creative Commons. licence, unless indicated otherwise in a credit line to the material. If material is not included in the article's Creative Commons licence and your intended use is not permitted by statutory regulation or exceeds the permitted use, you will need to obtain permission directly from the copyright holder. To view a copy of this licence, visit http://creativecommons.org/licenses/by/4.0/ The Creative Commons Public Domain Dedication waiver (http://creativecommons.org/publicdomain/zero/1.0/) applies to the data made available in this article, unless otherwise stated in a credit line to the data. 


\section{Background}

Acute kidney injury (AKI) has been an important research focus within intensive care medicine in recent years [1]. Incidence, risk factors, and outcome of AKI have been widely described [2-4]. The treatment options for AKI are limited, and consequently, long-term morbidity and mortality are substantial $[5,6]$. The lack of effective treatment options is partly explained by AKI being a complex and multifactorial syndrome [3] and, additionally, currently inadequately understood underlying pathophysiological mechanisms [7-9].

Septic AKI accounts for approximately 50\% of AKI cases in critically ill patients [7]. Given the heterogeneity of critically ill patients and their underlying illnesses, it is plausible that several subphenotypes of AKI exist, analogous to those in acute respiratory distress syndrome (ARDS) [10, 11] and in sepsis [12]. Recently, Bhatraju et al. described two possible subphenotypes of septic AKI in critically ill patients which had different outcomes in terms of renal recovery and mortality [13]. Identification of diagnostic subphenotypes of septic AKI may be crucial in order to improve prognostication and to identify different patient groups responding differently to treatment [14], as previously observed in AKI subphenotypes regarding vasopressin [13]. Schaub et al. suggested to pursue this type of research and investigate whether other markers that were not included by Bhatraju et al. could also aid in identifying subphenotypes of (septic) AKI [15].

Heterogeneity in the development, evolution, treatment effects, and outcomes of septic AKI may be explained by genetic factors, different comorbidities, other organ dysfunction, and expression of biomarkers following underlying pathophysiological processes [16]. These factors are not included in the current AKI KDIGO classification, using only serum creatinine and urinary output [17], which may be seen as an important limitation [18].

Multiple variables, including comorbidities, baseline clinical data, and biomarkers, are of potential use in identifying subphenotypes. Multicentre studies have aimed to identify biomarkers that could predict development, evolution, and outcome of AKI with mostly disappointing results [19-21]. We have previously evaluated multiple possible biomarkers of AKI in the FINNAKI cohort [2, 22-30].

We hypothesized that a combination of comorbidities, baseline clinical data, and multiple biomarkers could aid in the identification of subphenotypes in septic AKI upon ICU admission [28, 31]. Accordingly, we performed a post hoc analysis in critically ill patients with septic AKI using the prospectively collected FINNAKI cohort data [2] aiming at identifying subphenotypes of septic AKI.

\section{Methods}

\section{Study population}

Of the 2901 critically ill patients included in the FINNAKI study [2], we included all patients with septic AKI with biomarker data. The FINNAKI study was a prospective, observational, multicentre study in which 17 Finnish ICUs participated between 1 September 2011 and 1 February 2012. For the present study, we excluded 617 of the 918 septic FINNAKI patients [32]: 160 patients who did not give consent for biomarker analysis, 404 patients without AKI during the first $48 \mathrm{~h}$ of admission, and 53 patients with more than 6 missing values (50\%) for the 12 biomarkers (E-Fig. 3).

The Ethics Committee of the Department of Surgery in Helsinki University Central Hospital approved the FINNAKI study protocol with written informed consent from patients or their next of kin and the use of deferred consent. This study was reported in adherence to STROBE (Additional file 2).

\section{Definitions}

We defined AKI as any AKI of KDIGO stage one and higher within the first $48 \mathrm{~h}$ of admission, using the complete KDIGO criteria based on serum creatinine, urinary output, the combination of creatinine and urinary output, and use of renal replacement therapy (RRT) [33]. Sepsis was defined according to the initial ACCP/ SCCM Consensus Conference Committee definition and assessed prospectively by the researchers [34]. Modified SOFA on ICU admission was calculated as the SOFA score but leaving out the central nervous system (CNS) component, and the renal component was determined solely based on creatinine levels since urinary output data were not available on admission. Average vasopressor load $(\mu \mathrm{g} / \mathrm{kg} / \mathrm{min})$ during the first $24 \mathrm{~h}$ was calculated from norepinephrine equivalent vasopressors administered: [norepinephrine equivalents $(\mu \mathrm{g} / \mathrm{kg} / \mathrm{min})]=[$ norepinephrine $\mu \mathrm{g} / \mathrm{kg} / \mathrm{min})]+[$ dopamine $\quad(\mu \mathrm{g} / \mathrm{kg} / \mathrm{min})] /$ $2+$ [epinephrine $(\mu \mathrm{g} / \mathrm{kg} / \mathrm{min})]$.The primary outcome was 90-day mortality. The second outcome was renal recovery on day 5 , as renal recovery has been shown to be associated with improved outcomes after AKI and to allow comparison with similar studies. Day 5 was the last day of clinical data collection. Renal recovery on day 5 was defined as survival to 5 days and no AKI, which was based on the full KDIGO criteria using both serum creatinine and urinary output on day 5 .

\section{Variables}

We included previously analysed biomarkers, previously chosen based on the literature due to their association with the evolution or outcomes of AKI [35]. Clinical variables for the latent class analysis (LCA) were selected by clinical judgement and previous studies [36]. We 
restricted all class-defining variables to either permanent patient characteristics or variables measured from $24 \mathrm{~h}$ prior to admission to $2 \mathrm{~h}$ after admission. E-Table 3 lists all chosen class-defining variables.

\section{Statistical analysis}

We present data as means (with standard deviations (SD)) or medians (with interquartile ranges (IQR)) depending on distributions. Student's $t$ test, MannWhitney $U$ test, and Pearson's chi-squared test were used as appropriate. Outcomes were calculated as odds ratios (OR) with $95 \%$ confidence intervals $(\mathrm{CI})$. A $p$ value of $<0.05$ was considered statistically significant. $p$ values were not corrected for multiple comparisons in the analyses. Analyses were performed using Stata 15 and R (version 3.6.0).

First, we performed LCA to identify subphenotypes in septic AKI. Due to missing data, we performed a multiple imputation procedure on the data for LCA. Data were multiply imputed 31 times, using data for 615 septic patients, of which 301 constitute the analysed population of septic AKI patients. The 314 septic patients without AKI in the first $48 \mathrm{~h}$ were only included in the imputation model to improve the imputation procedure. We performed the LCA model for the 301 septic AKI patients on each imputed dataset separately, and the final class assignment was determined by taking the majority votes of the 31 models for each patient (see Additional file 1 for details). The optimal number of latent classes was decided by considering the Bayesian information criterion (BIC), the number of classes, class sizes, and entropy (see Additional file 1 for details).

Second, we used logistic regression to assess whether class membership was associated with different 90-day mortality and renal recovery on day 5 . We controlled for age and sex and measures of disease severity: APACHE II, admission modified SOFA score, KDIGO AKI stage, and presence of chronic or acute liver failure.

Last, as a confirmatory analysis, we performed a sensitivity analysis using data $24 \mathrm{~h}$ prior to and after ICU admission.

\section{Results}

Of 2901 FINNAKI study patients, 354 fulfilled inclusion criteria of which 301 patients had adequate biomarker data. Most of the characteristics of the included and excluded patients were similar (E-Table 4). Of the 301 patients, 166 patients (55\%) had AKI either on admission or within $24 \mathrm{~h}$ and 135 patients (45\%) were diagnosed with AKI between 24 and $48 \mathrm{~h}$. Of all patients, $127 \mathrm{pa}$ tients (42\%) had AKI based on creatinine only, 51 on urine output only $(17 \%)$, and 123 patients $(41 \%)$ on both or the use of RRT. Two- and three-class models were explored, and the two-class model for the LCA was selected based on BIC, entropy, and class sizes (see Additional file 1 for details including a comparison to the three-class model). In total, 133 patients (43\%) had phenotype 1 and 168 patients (57\%) had phenotype 2 . The mean probability of class membership in the model was 0.960 for subphenotype 1 and 0.959 for subphenotype 2.

Baseline characteristics of all 301 patients are shown in Table 1. Variable distribution differed across the subphenotypes (Fig. 1). Compared to subphenotype 1, subphenotype 2 was characterized by higher levels of heparin-binding protein (HBP), neutrophil elastase 2 (Ela), proteinase 3 (PRTN3), olfactomedin-4 (OLFM4), and matrix metalloproteinase 8 (MMP8). Figure 2 shows the standardized class-defining variable values by class, ranked by standardized mean difference (SMD). Of the clinical variables, patients with subphenotype 2 had lower BMI (27.3 vs $\left.30.3 \mathrm{~kg} / \mathrm{m}^{2}, p<0.001\right)$, were more likely to receive vasopressors ( $64 \%$ vs $48 \%, p=0.007)$, and had a lower prevalence of chronic kidney disease ( $4 \%$ vs $13 \%, p=0.005$ ). The timing of AKI diagnosis did not differ $(p=0.94)$. The median vasopressor load was higher in patients with subphenotype $2(0.28 \mathrm{vs} 0.18 \mu \mathrm{g} /$ $\mathrm{kg} / \mathrm{min}, p=0.009)$ as was the median fluid balance at 72 h ( 8286 vs $6738 \mathrm{~mL}, p=0.012)$ (Table 1$)$. In the sensitivity analysis using 24 -h data, 130 patients $(43 \%)$ had subphenotype 1 and 171 patients (57\%) had subphenotype 2 (E-Table 5), and distinctive variables and outcomes were the same as in the primary model (E-Fig. 4).

\section{Outcomes}

Renal recovery on day 5 occurred in 163 patients (54\%). At day 5, 42 patients (14\%) and at 90 days, 107 patients (36\%) had died. Logistic regression showed that membership in subphenotype 2 was associated with both decreased short-term renal recovery and increased mortality (Table 2).

\section{Discussion}

In this post hoc analysis of the multicentre prospective FINNAKI study, we identified two distinct subphenotypes of septic AKI, using variables on ICU admission in a cohort of critically ill patients. These findings remained unchanged in a model using variables obtained in the first $24 \mathrm{~h}$. Importantly, subphenotype 2 was associated with decreased short-term renal recovery and increased 90-day mortality.

Of the 30 included variables used in the LCA, four biomarkers showed the greatest difference between the two subphenotypes: HBP, Ela, PRTN3, and MMP8. Increased understanding of the underlying pathophysiologic mechanisms behind the subphenotypes represented by these biomarkers could aid in the design of future trials and further help treat septic AKI. HBP is a 
Table 1 Characteristics of study population per subphenotype

\begin{tabular}{|c|c|c|c|}
\hline & $\begin{array}{l}\text { Subphenotype } \\
1(n=133)\end{array}$ & $\begin{array}{l}\text { Subphenotype } \\
2(n=168)\end{array}$ & $p$ value \\
\hline Age, years (SD) & $64(15)$ & $65(15)$ & 0.58 \\
\hline Sex, male & $88(66 \%)$ & $97(58 \%)$ & 0.14 \\
\hline $\mathrm{BMl}, \mathrm{kg} / \mathrm{m}^{2}$ (SD) & $30.3(8.5)$ & $27.3(5.1)$ & $<0.001$ \\
\hline Operative admission & $28(21.2 \%)$ & $51(30.4 \%)$ & 0.074 \\
\hline Diabetes mellitus & $44(33.1 \%)$ & $44(26.2 \%)$ & 0.19 \\
\hline Chronic liver failure & $7(5.3 \%)$ & $3(1.8 \%)$ & 0.098 \\
\hline Chronic kidney disease & $17(13.1 \%)$ & $7(4.2 \%)$ & 0.005 \\
\hline $\begin{array}{l}\text { Baseline creatinine, } \\
\mathrm{mmol} / \mathrm{L}(\mathrm{SD})^{*}\end{array}$ & $91.1(55.9)$ & $86.7(50.3)$ & 0.55 \\
\hline Admission origin & & & 0.49 \\
\hline $\begin{array}{l}\text { Operation room/ } \\
\text { recovery }\end{array}$ & $28(21.1 \%)$ & $48(28.6 \%)$ & \\
\hline Emergency room & $55(41.4 \%)$ & $60(35.7 \%)$ & \\
\hline Ward & $39(29.3 \%)$ & $48(28.6 \%)$ & \\
\hline $\begin{array}{l}\text { Other ICU/high- } \\
\text { dependency unit/other }\end{array}$ & $11(8.3 \%)$ & $12(7.1 \%)$ & \\
\hline Timing of AKI & & & 0.94 \\
\hline Within $24 \mathrm{~h}$ & $73(54.9 \%)$ & $93(55.4 \%)$ & \\
\hline Within $48 \mathrm{~h}$ & $60(45.1 \%)$ & $75(44.6 \%)$ & \\
\hline \multicolumn{4}{|c|}{ Clinical variables on admission } \\
\hline Urinary tract infection & $12(9.0 \%)$ & $20(11.9 \%)$ & 0.42 \\
\hline Pneumonia & $26(19.5 \%)$ & $25(14.9 \%)$ & 0.28 \\
\hline Mechanical ventilation & $72(54.1 \%)$ & $78(46.4 \%)$ & 0.18 \\
\hline Vasopressors, any & $64(48.1 \%)$ & $107(63.7 \%)$ & 0.007 \\
\hline KDIGO AKI stage & & & 0.37 \\
\hline Stage 1 & $63(47.4 \%)$ & $67(39.9 \%)$ & \\
\hline Stage 2 & $22(16.5 \%)$ & $26(15.5 \%)$ & \\
\hline Stage 3 & $35(26.3 \%)$ & $60(35.7 \%)$ & \\
\hline $\begin{array}{l}\text { Modified SOFA on } \\
\text { admission (SD) }\end{array}$ & $6.0(2.6)$ & $6.4(2.5)$ & 0.20 \\
\hline APACHE II score (SD) & $27.3(9.4)$ & $27.8(8.6)$ & 0.66 \\
\hline $\begin{array}{l}\text { Mean arterial pressure, } \\
\mathrm{mmHg}(\mathrm{SD})\end{array}$ & $75(21)$ & $74(22)$ & 0.58 \\
\hline \multicolumn{4}{|c|}{ Biochemical variables on admission } \\
\hline $\begin{array}{l}\text { Leukocyte count, } \\
\times 10^{9} / \mathrm{L} \text { (SD) }\end{array}$ & $12.1(6.4)$ & $14.3(9.6)$ & 0.027 \\
\hline $\begin{array}{l}\text { Platelet count, } \\
\times 10^{9} / \mathrm{L}(\mathrm{SD})\end{array}$ & $232(125)$ & $202(143)$ & 0.064 \\
\hline Haematocrit (SD) & $0.35(0.07)$ & $0.35(0.08)$ & 0.90 \\
\hline CRP, nmol/L (SD) & $124(111)$ & $234(143)$ & $<0.001$ \\
\hline $\mathrm{pH}(\mathrm{SD})$ & $7.3(0.2)$ & $7.3(0.1)$ & 0.78 \\
\hline $\begin{array}{l}\text { Highest lactate, } \\
\mathrm{mmol} / \mathrm{L}(\mathrm{SD})\end{array}$ & $4.1(4.5)$ & $4.5(3.6)$ & 0.47 \\
\hline Base excess, lowest (SD) & $-6.2(9.1)$ & $-8.3(6.7)$ & 0.039 \\
\hline Creatinine, $\mu \mathrm{mol} / \mathrm{L}$ (SD) & $213(230)$ & $212(181)$ & 0.97 \\
\hline
\end{tabular}

Table 1 Characteristics of study population per subphenotype (Continued)

\begin{tabular}{|c|c|c|c|}
\hline & $\begin{array}{l}\text { Subphenotype } \\
1(n=133)\end{array}$ & $\begin{array}{l}\text { Subphenotype } \\
2(n=168)\end{array}$ & $p$ value \\
\hline \multicolumn{4}{|l|}{ Treatment } \\
\hline $\begin{array}{l}\text { Fluid balance at } 72 \mathrm{~h} \text {, } \\
\mathrm{mL} \text { (IQR) }\end{array}$ & $\begin{array}{l}6738(1868-10, \\
169)\end{array}$ & $\begin{array}{l}8286(4202-13, \\
671)\end{array}$ & 0.012 \\
\hline $\begin{array}{l}\text { Vasopressor load, } \\
\mu \mathrm{g} / \mathrm{kg} / \mathrm{min} \text { (IQR) }\end{array}$ & $0.18(0.04-0.44)$ & $0.28(0.12-0.69)$ & 0.009 \\
\hline $\begin{array}{l}\text { Renal replacement } \\
\text { therapy }\end{array}$ & $31(23.3 \%)$ & 66 (39.3\%) & 0.003 \\
\hline \multicolumn{4}{|l|}{ Outcomes } \\
\hline $\begin{array}{l}\text { SOFA score on day } 2 \\
\text { (SD) }\end{array}$ & $6.3(3.8)$ & $8.3(4.4)$ & $<0.001$ \\
\hline $\begin{array}{l}\text { SOFA score on day } 3 \\
\text { (SD) }\end{array}$ & $6.1(3.7)$ & $7.3(4.3)$ & 0.025 \\
\hline $\begin{array}{l}\text { Renal recovery on } \\
\text { day } 5\end{array}$ & 85 (63.9\%) & $78(46.4 \%)$ & 0.003 \\
\hline In-hospital mortality & $25(18.8 \%)$ & $60(35.7 \%)$ & 0.001 \\
\hline 90-day mortality & $39(29.3 \%)$ & $68(40.5 \%)$ & 0.045 \\
\hline
\end{tabular}

Description: Data are presented as numbers (percentages) or mean (SD)/ median (IQR). Vasopressors included here are norepinephrine, dobutamine, and epinephrine

$B M I$ body mass index, KDIGO Kidney Disease Improving Global Outcome, AKI acute kidney injury, SOFA Sequential Organ Failure Assessment, APACHE Acute Physiology, Age, Chronic Health Evaluation, CRP C-reactive protein

*Baseline serum creatinine was available for $69 \%$ of patients and, if missing, estimated using the MDRD formula

neutrophil-derived mediator for inflammation and vascular permeability and has been reported to improve the prediction of a clinical risk model in septic patients [28]. HBP reflects vascular permeability and was higher in patients with subphenotype 2 , who also received more fluids. The three other biomarkers Ela, PRTN3, and MMP8 are also neutrophil-derived proteases, which have previously been shown to accurately estimate the risk of AKI in septic children [37]. Notably, none of these four biomarkers is measured in standard clinical practice. The fact that these biomarkers appear higher in subphenotype 2 suggests that subphenotype 1 may represent a less severe form of septic AKI. Supporting this hypothesis, sCD73, a protective anti-inflammatory mediator, was higher in patients with subphenotype 1 [27]. Moreover, despite comparable SOFA and APACHE II scores on admission, this is reflected by higher vasopressor load and higher fluid balance later during admission in patients with subphenotype 2 . Clinically, patients with subphenotype 1 had a higher BMI and less severe metabolic acidosis. Although the number of patients with diagnosed chronic kidney disease was higher in subphenotype 1 , the baseline serum creatinine was comparable.

All previous studies except one [36] have classified AKI into different types of AKI based on renal outcome, but these subphenotypes were determined using outcome data retrospectively and not linked to 


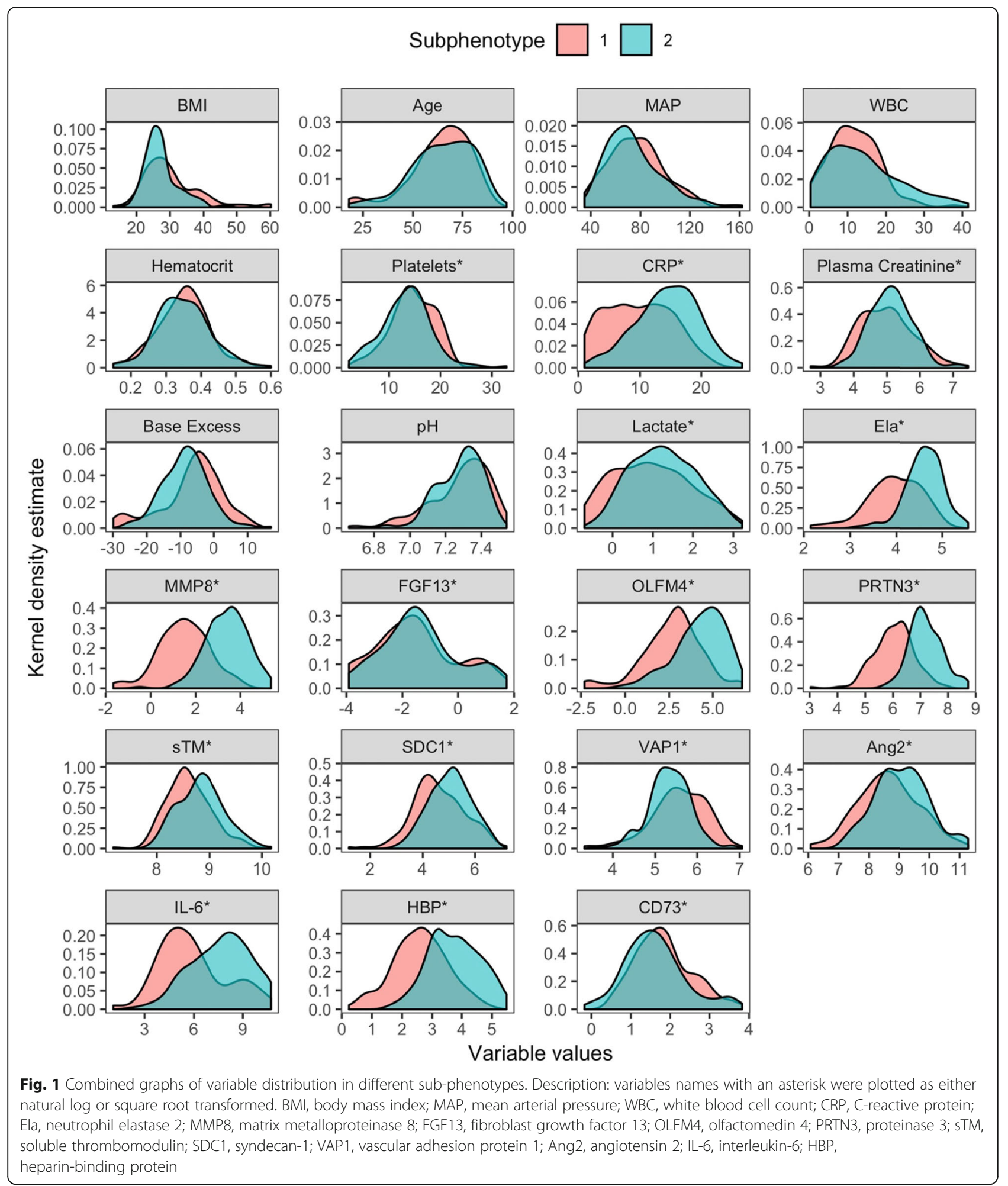

distinguishable pathophysiological pathways [38, 39]. Other studies have focused on subphenotypes of AKI in very specific contexts, such as kidney transplants [40] or experimental models [41]. Recently, however, two major studies using similar methods in critically ill patients with sepsis have been published [36, 42]. Different subphenotypes of sepsis have been identified in 16,552 critically ill patients. Although this study [42] did not focus on AKI specifically, the methodology is comparable to our study using a combination of baseline and clinical 


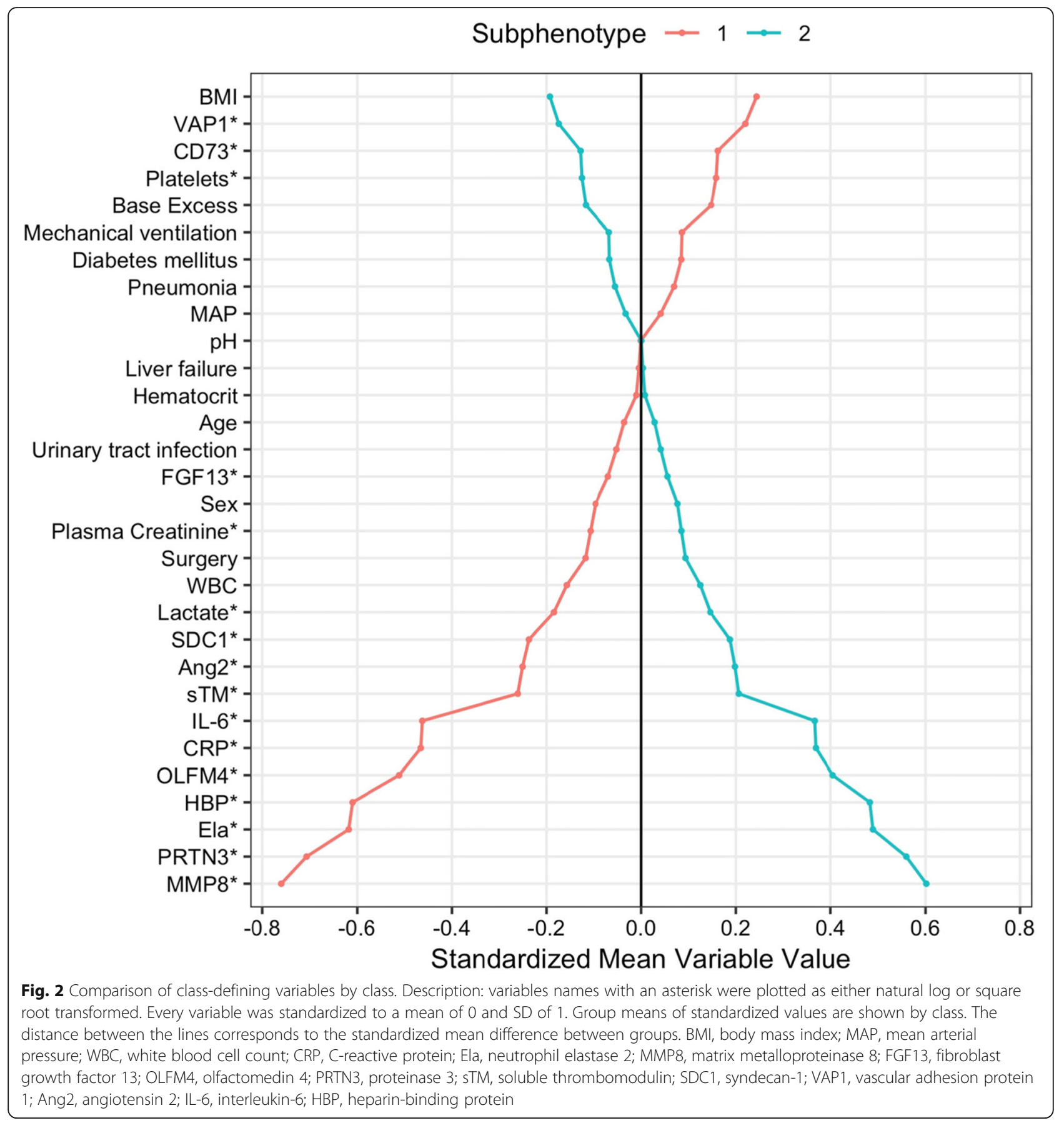

Table 2 Logistic regression, associations between subphenotype 2 membership and outcomes

\begin{tabular}{lllll}
\hline & Unadjusted OR $(95 \% \mathrm{Cl})$ & $p$ value & Adjusted* OR $(95 \% \mathrm{Cl})$ & $p$ value \\
\hline Renal recovery on day 5 & $0.49(0.31-0.78)$ & 0.003 & $0.47(0.27-0.79)$ & 0.005 \\
90-day mortality & $1.64(1.01-2.67)$ & 0.045 & $1.83(1.05-3.24)$ & 0.035 \\
\hline
\end{tabular}

Description: ORs are for subphenotype 2 vs. subphenotype 1

*Adjusted for age, sex, liver failure, modified SOFA score, APACHE II, and KDIGO AKI stage 
data to identify subphenotypes of a heterogeneous clinical syndrome [42].

More recently, Bhatraju et al. showed that two subphenotypes of AKI could be identified based on 29 variables using comparable methods [36]. The authors constructed a simplified three-variable model based on the ratio between plasma angiopoietin 2 (Ang-2) and angiopoietin 1 (Ang-1) and $\mathrm{s}$ TNF receptor 1 , which was able to distinguish between the subphenotypes. The model performed well. We analysed similar outcomes, primarily 90-day mortality and short-term renal recovery, although the latter is inevitably subject to competing risk of death. However, some major methodological differences exist. First, we focused on patients with septic AKI only whereas in the cohorts of Bhatraju et al., sepsis incidences range from $46 \%$ to $84 \%$ throughout the subphenotypes across the cohorts. Second, despite a large cohort of concomitant ICU patients, we were able to include only 301 patients with septic AKI in this study. Although we had to exclude 53 patients due to inadequate biomarker data, we consider the included patients to represent the cohort since their baseline characteristics were comparable to those excluded. Third, the model by Bhatraju et al. was investigated in a development cohort and thereafter validated in separate cohorts, which adds validity to their model. Fourth, however, instead of preempt restricted time points for biomarkers, Bhatraju et al. included biomarkers collected at various points within $24 \mathrm{~h}$ of AKI diagnosis, which may vary, and some were measured at study enrolment (which was, for example, $12 \mathrm{~h}$ after meeting criteria for inclusion in the VASST trial [43]). Of note, in our primary model, we only included data available on ICU admission, as this approach is most clinically relevant for future implementation and potential guide for treatment. Finally, we included 12 markers that reflect either endothelial dysfunction or inflammation, where a panel of inflammatory markers was most prominent, compared to Bhatraju et al. who included eight biomarkers reflecting similar underlying pathophysiology [36]. In comparison, we included 18 of those 29 variables in the Bhatraju model. Among these were two biomarkers, namely Ang-2 and interleukin-6, and both showed comparable associations with the more severe subphenotype of septic AKI, although Ang-2 was less distinctive in our results.

\section{Implications and generalizability}

We were able to identify two subphenotypes of septic AKI that have different clinical outcomes. As our model is based on variables available on ICU admission only, we consider our observations important for potential implementation in selecting patients for trials and potentially for future therapeutic options. Our findings need further external validation in other cohorts but encourage for future (prospective) research to combine clinical and biomarker data in search for ways to decrease heterogeneity and aim for precision care [44]. If confirmed, our findings regarding additional discriminative value support the use of a biomarker panel including HBP and neutrophil-derived proteases in critically ill patients with septic AKI. Notably, the classification of the two distinct subphenotypes remained stable using 24-h clinical data increasing its clinical potential on ICU admission. Moreover, future studies could perform similar analyses in septic patients in general to assess whether a combination of biomarkers could aid in identifying patients at increased risk of adverse outcomes.

\section{Limitations}

There are some important limitations to consider. First, there are multiple potential ways of classifying patients through unsupervised learning [45]. Even in the context of LCA, classification is dependent on the choice of class-defining variables, number of classes, and model parameters. Although we selected variables based on current literature and clinical expertise, classifying patients using some other combination of clinical data, biomarkers, and other types of data could lead to a different classification. Also, our sample size was somewhat limited for unsupervised learning. However, we mitigated this problem by first defining the final LCA model without examining the outcomes and examined associations between class membership and outcomes only after the final model was specified, thus avoiding overfitting our classification to the outcomes. Due to sample size limitations, we did not attempt to internally validate the results on a held-out dataset. Moreover, similar analyses on larger samples might end up at more than two distinct classes. Nonetheless, the lack of validation is an important limitation to our study. Second, we defined our population of patients with AKI by selecting those that had AKI within the first $48 \mathrm{~h}$ of admission. Although more than half had AKI during the first day, the definition of AKI still has a delay as opposed to the actual renal injury and we, therefore, consider that it did not influence our result as confirmed by the 24-h model. Moreover, we have previously shown that the majority of patients develop AKI within the first 2 days. We suspect that biomarkers measured on ICU admission would not be associated with AKI occurring later. Thus, we believe that the results are representative. Additionally, the outcome renal recovery was determined on day 5 , while 7 days would be the optimal follow-up period. However, day 5 was the last observation day within this study. Third, this was a post hoc analysis of prospectively gathered clinical and laboratory data-all laboratory measurements were not available for all patients but were 
multiply imputed. Thus, to assess the usefulness of the subphenotypes, they would ultimately have to be validated in a prospective setting. Moreover, our sample size limited the number of classes that can be reliably studied. In a larger sample, it could be possible to determine more than two classes and assess their association with the outcomes. Yet, a previous study using a similar methodology with a larger sample size ended up with two classes as well [36]. However, we focused on septic AKI due to possible different pathophysiological mechanisms underlying different types of AKI. Fourth, sepsis was defined according to the definition by the American College of Chest Physicians/Society of Critical Care Medicine (ACCP/SCCM) [34]. This was, at the time of patient inclusion for the FINNAKI study, the used definition. Using the sepsis-3 definition was not possible given the data. Similarly, at the time, colloids were still regularly administered. It is important to note that prominent changes in process of care or definitions of disease over time may impact the clinical outcomes of sub-phenotypes. Finally, as this was an observational study with usual care, causal inferences regarding any suggested treatments cannot be drawn. Ultimately the goal will be to prospectively evaluate how different phenotypes respond to different types of treatment in randomized clinical trials stratified according to these or other detected subphenotypes of AKI.

\section{Conclusions}

In this post hoc analysis using data from a prospective observational study, we were able to identify two subphenotypes of septic AKI with statistically significantly different 90-day mortality and rate of short-term renal recovery. The subphenotypes were primarily classified using variables on admission only but were robust to a sensitivity analysis using clinical variables of the first 24 h. These detected subphenotypes warrant prospective external validation.

\section{Supplementary information}

Supplementary information accompanies this paper at https://doi.org/10. 1186/s13054-020-02866-X.

Additional file 1. Detailed description of statistical analysis. E-Table 1: Comparison of latent class analysis models with different numbers of classes. E-Table 2: Pearson correlations of class defining variables with absolute correlations over 0.5. E-Table 3: List of variables included in multiple imputation and percentages of missing data. E-Table 4: All included variables for clustering. E-Table 5. Comparison of baseline characteristics between included and excluded patients. E-Table 6. Baseline of patients in class of 24-hour variable model. E-Table 7. Comparison of admission and 24-hour model classification. E-Figure 1: First two principal components of the variables used in the LCA, two class and three class model comparison. E-Figure 2: Heatmap of class assignments for the admission model across 31 imputations. E-Figure 3: Flowchart of patient inclusion. E-Figure 4: Standardized mean difference (SMD) plot of class defining variables of 24-hour model.
Additional file 2. STROBE checklist and corresponding page numbers.

\section{Abbreviations}

AKI: Acute kidney injury; ANG: Angiotensin; APACHE: Acute Physiology, Age, Chronic Health Evaluation; ARDS: Acute respiratory distress syndrome; BIC: Bayesian information criterion; Ela: Neutrophil elastase 2; HBP: Heparinbinding protein; ICU: Intensive care unit; IQR: Interquartile range;

KDIGO: Kidney Disease Improving Global Outcome; LCA: Latent class analysis; MMP 8: Matrix metalloproteinase 8; OLFM4: Olfactomedin 4; OR: Odds ratio; PRTN3: Proteinase 3; RRT: Renal replacement therapy; SD: Standard deviation; SMD: Standardized mean difference; SOFA: Sequential Organ Failure

Assessment; TNF: Tumour necrosis factor

\section{Acknowledgements}

We are extremely grateful for all members of the FINNAKI study group for their participation in data collection.

\section{Authors' contributions}

RW and SJ drafted the manuscript and conducted the analyses. VP and STV created the idea of the study. MP, PL, HW, AL, and IvdH critically reviewed the manuscript and agreed with the final version and findings. The authors read and approved this manuscript.

\section{Funding}

The FINNAKI study has been supported by the Academy of Finland, the Sigrid Juselius Foundation, Päivikki and Sakari Sohlberg Foundation, and Institutional Grants from the Helsinki University Hospital (TYH2013343, TYH2016243, TYH2017241). STV has received funding for Clinical Researchers (317061) from the Academy of Finland.

\section{Availability of data and materials}

The datasets used and/or analysed during the current study are available from the corresponding author on reasonable request.

Ethics approval and consent to participate

The Ethics Committee of the Department of Surgery in Helsinki University Central Hospital approved the FINNAKI study protocol with written informed consent from patients or their next of kin and the use of deferred consent.

\section{Consent for publication}

Not applicable.

\section{Competing interests}

A.L. is listed as of the inventors on a patent on the use of HBP as a diagnostic tool in sepsis filed by Hansa Medical AB. All other authors declare that they have no competing interests.

\section{Author details}

'Department of Critical Care, University of Groningen, University Medical Center Groningen, Groningen, The Netherlands. ${ }^{2}$ Division of Intensive Care Medicine, Department of Anesthesiology, Intensive Care and Pain Medicine, University of Helsinki and Helsinki University Hospital, Helsinki, Finland. ${ }^{3}$ Department of Anesthesiology and Intensive Care, Lapland Central Hospital, Rovaniemi, Finland. ${ }^{4}$ Department of Clinical Chemistry and Hematology, University of Helsinki and Helsinki University Hospital and Minerva Foundation Institute for Medical Research, Helsinki, Finland. ${ }^{5}$ Division of Critical Care Medicine, Department of Pediatrics, Cincinnati Children's Hospital Medical Center, University of Cincinnati College of Medicine, Cincinnati, OH, USA. ${ }^{6}$ Department of Clinical Sciences, Division of Infection Medicine, Lund University, Lund, Sweden. ${ }^{7}$ Department of Intensive Care, Maastricht University Medical Centre+, University Maastricht, Maastricht, The Netherlands.

Received: 2 December 2019 Accepted: 31 March 2020

Published online: 15 April 2020

References

1. Pickkers P, Ostermann M, Joannidis M, Zarbock A, Hoste E, Bellomo R, et al. The intensive care medicine agenda on acute kidney injury. Intensive Care Med. Department of Intensive Care Medicine (710), Radboud University 
Medical Centre, Geert Grooteplein Zuid 10, P.O. Box 9101, 6500 HB, Nijmegen, The Netherlands.; Department of Critical Care, Guy's and St Thomas' Hospital, King's College London, Lon (TRUNCATED; 2017;

2. Nisula S, Kaukonen K-M, Vaara ST, Korhonen A-M, Poukkanen M, Karlsson S, et al. Incidence, risk factors and 90-day mortality of patients with acute kidney injury in Finnish intensive care units: the FINNAKI study. Intensive Care Med. 2013;39:420-8 Available from: https://doi.org/10.1007/s00134-0122796-5.

3. Hoste EAJ, Kellum JA, Selby NM, Zarbock A, Palevsky PM, Bagshaw SM, et al. Global epidemiology and outcomes of acute kidney injury. Nat Rev Nephrol. England: Nature Publishing Group; 2018 [cited 2018 Sep 4];14. Available from: http://www.nature.com/articles/s41581-018-0052-0.

4. Chertow GM, Burdick E, Honour M, Bonventre JV, Bates DW. Acute kidney injury, mortality, length of stay, and costs in hospitalized patients. J Am Soc Nephrol. 2005;16:3365-70.

5. Mildh H, Pettila V, Korhonen AM, Karlsson S, Ala-Kokko T, Reinikainen M, et al. Three-year mortality in 30-day survivors of critical care with acute kidney injury: data from the prospective observational FINNAKI study. Ann Intensive Care. 2016;6:118.

6. Wald R, Quinn RR, Adhikari NK, Burns KE, Friedrich JO, Garg AX, et al. Risk of chronic dialysis and death following acute kidney injury. Am J Med. Elsevier; 2012 [cited 2018 Sep 19];125:585-93. Available from: https:/www. sciencedirect.com/science/article/pii/S0002934312000939?via\%3Dihub.

7. Pettilä V, Bellomo R. Understanding acute kidney injury in sepsis. Intensive Care Med. Springer Berlin Heidelberg; 2014 [cited 2018 Sep 4];40:1018-20. Available from: http://link.springer.com/10.1007/s00134-014-3313-9.

8. Langenberg C, Bagshaw SM, May CN, Bellomo R. The histopathology of septic acute kidney injury: a systematic review. Crit Care; 2008 [cited 2018 Sep 19];12:R38. Available from: http://ccforum.biomedcentral.com/articles/1 $0.1186 /$ cc6823.

9. Kinsey GR, Okusa MD. Pathogenesis of acute kidney injury: foundation for clinical practice. Am J Kidney Dis; 2011 [cited 2018 Sep 19];58:291-301. Available from: http://www.ncbi.nlm.nih.gov/pubmed/21530035.

10. Calfee CS, Delucchi KL, Sinha P, Matthay MA, Hackett J, Shankar-Hari M, et al. Acute respiratory distress syndrome subphenotypes and differential response to simvastatin: secondary analysis of a randomised controlled trial. Lancet Respir Med; 2018 [cited 2018 Sep 4];6:691-8. Available from: https:// www.sciencedirect.com/science/article/pii/S2213260018301772?via\%3Dihub.

11. Lawler PR, Fan E. Heterogeneity and phenotypic stratification in acute respiratory distress syndrome. Lancet Respir Med; 2018 [cited 2018 Sep 4];6: 651-3. Available from: https://www.thelancet.com/journals/lanres/article/ PIIS2213-2600(18)30287-X/abstract.

12. Seymour CW, Kennedy JN, Wang S, Chang C-CH, Elliott CF, Xu Z, et al. Derivation, Validation, and Potential Treatment Implications of Novel Clinical Phenotypes for Sepsis. JAMA; 2019 [cited 2019 Jun 17]:321:2003. Available from: http://jama.jamanetwork.com/article.aspx?doi=10.1001/jama.2019.5791.

13. Bhatraju PK, Zelnick LR, Herting J, Katz R, Mikacenic C, Kosamo S, et al. Identification of acute kidney injury subphenotypes with differing molecular signatures and responses to vasopressin therapy. Am J Respir Crit Care Med; 2019 [cited 2019 Jun 17];199:863-72. Available from: https://www. atsjournals.org/doi/10.1164/rccm.201807-13460C

14. Iwashyna TJ, Burke JF, Sussman JB, Prescott HC, Hayward RA, Angus DC. Implications of heterogeneity of treatment effect for reporting and analysis of randomized trials in critical care. Am J Respir Crit Care Med; 2015 [cited 2018 Sep 4];192:1045-51. Available from: http://www.atsjournals.org/doi/1 $0.1164 / \mathrm{rccm} .201411-2125 \mathrm{CP}$

15. Schaub JA, Heung M. Precision Medicine in acute kidney injury: a promising future? Am J Respir Crit Care Med; 2019 [cited 2019 Jun 17];199:814-6. Available from: https:/www.atsjournals.org/doi/10.1164/rccm.201810-2032ED

16. Peters E, Antonelli M, Wittebole X, Nanchal R, François B, Sakr Y, et al. A worldwide multicentre evaluation of the influence of deterioration or improvement of acute kidney injury on clinical outcome in critically ill patients with and without sepsis at ICU admission: results from The Intensive Care Over Nations audit. Crit Care : 2018 [cited 2018 Sep 4]:22:188. Available from: https://ccforum.biomedcentral.com/articles/10.1186/s13054018-2112-z.

17. KDIGO Clinical practice guideline for acute kidney injury. Kidney Int Suppl. 2012;2. Available from: https://doi.org/10.1038/kisup.2012.1.

18. Barry R, James MT. Guidelines for classification of acute kidney diseases and disorders. Nephron. Switzerland: Karger Publishers; 2015 [cited 2018 Sep 4];131: 221-6. Available from: https:/www.karger.com/Article/FullText/441425\#ref11.
19. Endre ZH. Assessing renal recovery after acute kidney injury: can biomarkers help? Nephron.; 2018 [cited 2018 Sep 4];140:86-9. Available from: https:// www.karger.com/Article/FullText/492290\#ref12.

20. Bagshaw SM, Bennett M, Devarajan P, Bellomo R. Urine biochemistry in septic and non-septic acute kidney injury: a prospective observational study. J Crit Care; 2013 [cited 2018 Sep 4];28:371-8. Available from: https://www. sciencedirect.com/science/article/pii/S0883944112003346?via\%3Dihub.

21. Gayat E, Touchard C, Hollinger A, Vieillard-Baron A, Mebazaa A, Legrand M. Back-to-back comparison of penKID with NephroCheck ${ }^{\circledR}$ to predict acute kidney injury at admission in intensive care unit: a brief report. Crit Care ; 2018 [cited 2018 Sep 19];22:24. Available from: https://ccforum. biomedcentral.com/articles/10.1186/s13054-018-1945-9.

22. Nisula S, Yang R, Kaukonen K-M, Vaara ST, Kuitunen A, Tenhunen J, et al. The urine protein NGAL predicts renal replacement therapy, but not acute kidney injury or 90-day mortality in critically ill adult patients. Anesth Analg. 2014 [cited 2018 Sep 19];119:95-102. Available from: http://www.ncbi.nlm. nih.gov/pubmed/24806144.

23. Marttinen M, Wilkman E, Petäjä L, Suojaranta-Ylinen R, Pettilä V, Vaara ST. Association of plasma chloride values with acute kidney injury in the critically ill - a prospective observational study. Acta Anaesthesiol Scand Wiley/Blackwell (10.1111); 2016 [cited 2018 Sep 4];60:790-9. Available from: http://doi.wiley.com/10.1111/aas.12694.

24. Nisula S, Yang R, Poukkanen M, Vaara SST, Kaukonen KMK-M, Tallgren M, et al. Predictive value of urine interleukin-18 in the evolution and outcome of acute kidney injury in critically ill adult patients. Br J Anaesth ; 2015 [cited 2018 Sep 4];114:460-8. Available from: https://www.sciencedirect.com/ science/article/pii/S0007091217318123?via\%3Dihub.

25. Mårtensson J, Vaara ST, Pettilä V, Ala-Kokko T, Karlsson S, Inkinen O, et al. Assessment of plasma endostatin to predict acute kidney injury in critically ill patients. Acta Anaesthesiol Scand. Wiley/Blackwell (10.1111); 2017 [cited 2018 Sep 19];61:1286-95. Available from: http://doi.wiley com/10.1111/aas.12988.

26. Hästbacka J, Linko R, Tervahartiala T, Varpula T, Hovilehto S, Parviainen I, et al. Serum MMP-8 and TIMP-1 in critically ill patients with acute respiratory failure: TIMP-1 is associated with increased 90-day mortality. Anesth Analg. 2014 [cited 2018 Sep 19];118:790-8. Available from: https://insights.ovid. com/crossref?an=00000539-201404000-00016

27. Vaara ST, Hollmén M, Korhonen A-M, Maksimow M, Ala-Kokko T, Salmi M, et al. Soluble CD73 in critically ill septic patients - data from the prospective FINNAKI study. Khodarahmi R, editor. PLoS One; 2016 [cited 2018 Sep 19];11:e0164420. Available from: http://dx.plos.org/10.1371/journal. pone.0164420.

28. Tverring J, Vaara ST, Fisher J, Poukkanen M, Pettilä V, Linder A. Heparinbinding protein (HBP) improves prediction of sepsis-related acute kidney injury. Ann Intensive Care; 2017 [cited 2018 Sep 4];7:105. Available from: http://annalsofintensivecare.springeropen.com/articles/10.1186/s13613-0170330-1.

29. Wong HR, Cvijanovich NZ, Anas N, Allen GL, Thomas NJ, Bigham MT, et al. A multibiomarker-based model for estimating the risk of septic acute kidney injury. Crit Care Med. 2015 [cited 2019 Jun 19];43:1646-53. Available from: https://insights.ovid.com/crossref?an=00003246-201508000-00012.

30. Vaara ST, Lakkisto P, Immonen K, Tikkanen I, Ala-Kokko T, Pettilä V, et al. Urinary biomarkers indicative of apoptosis and acute kidney injury in the critically ill. Ricci Z, editor. PLoS One ; 2016 [cited 2018 Sep 4];11:e0149956. Available from: http://dx.plos.org/10.1371/journal.pone.0149956.

31. Kellum JA, Sileanu FE, Bihorac A, Hoste EAJ, Chawla LS. Recovery after acute kidney injury. Am J Respir Crit Care Med. 2017;195:784-91.

32. Poukkanen M, Vaara ST, Pettilä V, Kaukonen K-MK-M, Korhonen A-MA-M Hovilehto S, et al. Acute kidney injury in patients with severe sepsis in Finnish Intensive Care Units. Acta Anaesthesiol Scand. England; 2013 [cited 2018 Sep 4];57:863-72. Available from: http://www.stat.fi.

33. Kellum JA. Diagnosis, evaluation, and management of acute kidney injury: a KDIGO summary (part 1). Crit Care. 2013;17. Available from: https://doi.org/ 10.1186/cc11454

34. Bone RC, Balk RA, Cerra FB, Dellinger RP, Fein AM, Knaus WA, et al. Definitions for sepsis and organ failure and guidelines for the use of innovative therapies in sepsis. Chest ; 1992 [cited 2018 Sep 4];101:1644-55. Available from: https://www.sciencedirect.com/science/article/pii/S001236 921638415X?via\%3Dihub.

35. Basu RK, Standage SW, Cvijanovich NZ, Allen GL, Thomas NJ, Freishtat RJ, et al. Identification of candidate serum biomarkers for severe septic shock- 
associated kidney injury via microarray. Crit Care. 2011 [cited 2019 Jun 19]; 15:R273. Available from: http://ccforum.biomedcentral.com/articles/10.1186/ cc10554.

36. Bhatraju PK, Zelnick LR, Herting J, Katz R, Mikacenic C, Kosamo S, et al. Identification of acute kidney injury subphenotypes with differing molecular signatures and responses to vasopressin therapy. Am J Respir Crit care med. Am Thoracic Society. 2019;199:863-72.

37. Wong HR, Cvijanovich NZ, Anas N, Allen GL, Thomas NJ, Bigham MT, et al. A multibiomarker-based model for estimating the risk of septic acute kidney injury. Crit Care Med. 2015;43:1646-53.

38. Sood MM, Shafer LA, Ho J, Reslerova M, Martinka G, Keenan S, et al. Early reversible acute kidney injury is associated with improved survival in septic shock. J Crit Care. 2014;29:711-7.

39. Bhatraju PK, Mukherjee P, Robinson-Cohen C, O'Keefe GE, Frank AJ, Christie $J \mathrm{D}$, et al. Acute kidney injury subphenotypes based on creatinine trajectory identifies patients at increased risk of death. Crit Care. 2016;20:372.

40. Famulski KS, de Freitas DG, Kreepala C, Chang J, Sellares J, Sis B, et al. Molecular phenotypes of acute kidney injury in kidney transplants. J Am Soc Nephrol. 2012;23:948-58.

41. Xu K, Rosenstiel P, Paragas N, Hinze C, Gao X, Huai Shen T, et al. Unique transcriptional programs identify subtypes of AKI. J Am Soc Nephrol. 2017; 28:1729-40.

42. Seymour CW, Kennedy JN, Wang S, Chang C-CH, Elliott CF, Xu Z, et al. Derivation, validation, and potential treatment implications of novel clinical phenotypes for sepsis. JAMA. 2019;321:2003.

43. Russell JA, Walley KR, Singer J, Gordon AC, Hébert PC, Cooper DJ, et al, Vasopressin versus norepinephrine infusion in patients with septic shock. N Engl J Med ; 2008 [cited 2019 Jun 19];358:877-87. Available from: http:// www.nejm.org/doi/abs/10.1056/NEJMoa067373.

44. Schaub JA, Heung M. Precision medicine in acute kidney injury: a promising future? Am J Respir Crit care med. Am Thoracic Soc. 2019;199:814-6.

45. Castela Forte J, Perner A, van der Horst ICC. The use of clustering algorithms in critical care research to unravel patient heterogeneity. Intensive Care Med; 2019 [cited 2019 Jun 27];1-4. Available from: http://link.springer.com/1 0.1007/s00134-019-05631-z

\section{Publisher's Note}

Springer Nature remains neutral with regard to jurisdictional claims in published maps and institutional affiliations.

Ready to submit your research? Choose BMC and benefit from:

- fast, convenient online submission

- thorough peer review by experienced researchers in your field

- rapid publication on acceptance

- support for research data, including large and complex data types

- gold Open Access which fosters wider collaboration and increased citations

- maximum visibility for your research: over $100 \mathrm{M}$ website views per year

At $\mathrm{BMC}$, research is always in progress.

Learn more biomedcentral.com/submissions 